\title{
Defining a Particular Social Group Based on Gender
}

\author{
Elizabeth Adjin-Tettey
}

\begin{abstract}
It is now accepted in refugee jurisprudence that gender-based social groups fall within the meaning of Particular Social Group for purposes of according Convention refugee protection. However, the criteria for identifying genderbased social groups remains to be settled. The tendency has been to identify the at-risk group by the common victimization which confronts group members. This is neither innate nor constant. The author takes the position that the group should simply be identified by the gender of its members-women, although there may be subgroups of women united by other characteristics such as race, nationality or religion. Not all group members will automatically be eligible for refugee protection; only women who are genuinely at risk of persecution will be accorded Convention refugee status.

Précis
\end{abstract}

Il est maintenant reconnu, dans la jurisprudence en matière de droit des réfugiés, que les groupes sociaux fondés sur le sexage sont un type de groupe social particulier aux fins de l'allocation des protections dues aux réfugiés en vertu de la Convention. Cependant, le critère d'identification des groupes sociaux fondés sur le sexage reste a définir. La tendance a été à identifier les groupes à risque par le dénominateur commun de la victimisation à laquelle les membres du groupe sont confrontés. Ceci n'est ni une inhérence ni une constance. L'auteure du présent article assume la position que le groupe deorait simplement être identifié de par le sexe de ses membres: des femmes, quoiqu'ily ait des sous-groupes de femmes unis par d'autres caractéristiques, telles la race,

Elizabeth Adjin-Tettey, Ph.D., is a lecturer in the Department of Law, Carleton University, Ottawa. la nationalité ou la religion. Ce ne sont pas tous les membres du groupe qui seront automatiquement éligibles au statut de réfugié: seules les femmes qui sont réellement confrontées à un sérieux danger de persécution obtiendrons le statut de réfugiées en vertu de la Convention.

Eligibility for Convention refugee protection depends on the ability to establish a nexus between a well-founded fear of persecution and the claimant's civil or political status. The Convention refugee regime limits protection to persons who face a genuine fear of persecution by reason of their race, nationality, religion, political opinion or membership of a particular social group. The particular social group category is proving to be a very versatile ground for recognizing claims arising from gender-based persecution and other non-enumerated grounds for according convention refugee status.

Contemporaryjurisprudence on the definition of "Convention refugee" unequivocally recognizes that "gender" is a particular social group. Hathaway states that "Gender-based groups are clear examples of social subsets defined by an innate and immutable characteristic. Thus, while gender is not an independent enumerated ground for Convention protection, it is properly within the ambit of the social group category."1

In A.G. v. Ward, the Supreme Court of Canada stressed the element of immutability in defining a "membership in a particular social group." After reviewing scholarship and jurisprudence on the meaning of the particular social group category, Mr. Justice La Forest identified three possible categories for defining a social group within the meaning of the Convention refugee definition. These are groups defined by an innate or unchangeable characteristic; groups whose members voluntarily associate for reasons so fundamental to their human dignity that they should not be forced to forsake the association; and groups associated by a former voluntary status, unalterable due to its historical permanence. ${ }^{2}$

Reference to an innate characteristic, such as sex, as defining a particular social group ensures that women or a subset of women in a particular society may be considered a particular social group for purposes of according Convention refugee protection when they are susceptible to serious harm for no other reason than being women. Indeed, this possibility was recognized by the Supreme Court of Canada in A.G. v. Ward. Mr. Justice La Forest noted that the first category of persons united by an innate or unchangeable characteristic would encompass individuals fearing persecution on the basis of their gender. ${ }^{3}$ Recognition of gender as identifying a social group is supported by the Canadian Gender Guidelines. ${ }^{4}$

Though the Supreme Court of Canada has clearly declared that gender can be the basis for identifying a particular social group, some confusion remains regarding whether gender alone can constitute the basis of the social group, or whether gender might be one characteristic that must combine with others to define the social group. The Canadian Guidelines are in part the source of this ambiguity, since they concede that while being a woman per se could entitle one to membership in a social group, the size of the group could be limited by the common victimization or vulnerability of the members of the group to persecution. ${ }^{5}$ This approach attempts to define the group by reference to the nature of persecution feared. It also suggests that the group is defined by reference to gender and some other characteris- 
tic, usually the common victimization which confronts group members.

This was the position adopted by Mr. Justice Mahoney in the pre-Ward decision of Mayers v. M.E.I. ${ }^{6}$ in which the Federal Court of Appeal held that the claimant belonged to a social group comprising "Trinidadian women subject to wife abuse." Mahoney's approach to the definition of a particular social group was adopted by Mr. Justice Linden in Cheung v. M.E.I. ${ }^{7}$ After reviewing the Mayers decision, $\mathrm{Mr}$. Justice Linden concluded that "women in China who have more than one child and are faced with forced sterilization because of this form a particular social group so as to come within the meaning of the definition of Convention refugee." 8

This approach finds further support from the Ward decision. By saying that a particular social group cannot be defined solely by reason of the common victimization of its members, $\mathrm{Mr}$. Justice La Forest appears to be suggesting that the common vulnerability of the group, combined with other characteristic(s) may be sufficient to delineate a particular social group. Thus, in spite of the guidelines for identifying the existence of a particular social group outlined in the Ward decision-immutable characteristics, voluntary association for reasons fundamental to human identity and former voluntary status-some postWard decisions continue to define gender-based social groups by reference to the common victimization which confronts its members. In Narvaez $v$. Minister of Citizenship \& Immigration, $\mathrm{Mr}$. Justice McKeown took the position that women in Ecuador subject to domestic violence constitute a particular social group. ${ }^{9}$

This approach is problematic. Though the anti-discrimination approach to identifying a social group presupposes that the members of the group are susceptible to victimization, naming a particular harm feared as the basis of defining the group deviates from the focus on immutability as the foundation of gender-based social groups. The common victimization confronting the group is of course not innate, and is clearly not the basis upon which the harm is feared. This critique has sometimes been acknowledged by the Canadian Immigration and Refugee Board, as in the case of America Torres. The claimant, a citizen of Ecuador, was allegedly fearful of persecution by reason of her membership in a particular social group, i.e., abused women who do not receive any effective protection from the home state. The panel was of the view that defining a social group by reference to the particular harm feared is circular. "A claimant must fear persecution for a Convention reason. The Convention reason must preexist the persecution. To argue that someone is persecuted for the reason that she is persecuted is [nonsensical]." 10

It appears more logical to define groups in terms of vulnerability in general because of an innate characteristic, rather than by reference to particular forms of vulnerability. ${ }^{11}$ Understood in this way, women constitute a particular social group both because of an innate characteristic that they share (gender), and because of their susceptibility to serious human rights violations. ${ }^{12}$ The fact that not all women are targets of gender-related serious human rights abuses at any one particular time does not affect the designation of women as a particular social group. After all, all group members need not be at risk of persecution before they can be recognized as a "particular social group." This position has been affirmed by the Supreme Court of Canada. In Brooks v. Canada Safeway $L t d .{ }^{13}$ the appellant, whobecame pregnant while in the employ of the respondents, alleged that a group insurance plan maintained by the latter that excluded payment of benefits to pregnant women during a seventeen week period even if they suffered from an ailment totally unrelated to pregnancy amounted to sex discrimination. The respondents were of the view that since not all women became pregnant, pregnancy related discrimination was not sex discrimination. In allowing the appeal, the Chief Justice noted that pregnancy related discrimination amounts to discrimination on the basis of sex, even though not all women become pregnant at any one time. He pointed out that pregnancy cannot be separated from gender. "While pregnancy-based discrimination only affects part of an identifiable group, it does not affect anyone who is not a member of the group... This fact does not make the impugned distinction any less discriminatory." ${ }^{14}$

The prevalence of discrimination and violence against women, especially in the so-called "private sphere," is common knowledge. ${ }^{15}$ Thus, being a woman in and of itself is so full of risks that some states have not been particularly enthusiastic in recognizing a social group that potentially has millions of members. Such concerns are defeated by the ejusdem generis approach since the other four categories-race, nationality, religion and political opinion-are characteristics which are also shared by large numbers of people. ${ }^{16}$ The Canadian Gender Guidelines note that "the fact that the particular social group consists of large numbers of the female population in the country concerned is irrelevant-race, religion, nationality and political opinion are also characteristics that are shared by large numbers of people."17

Just being a woman in some societies, makes one susceptible to human rights violations committed with impunity, particularly in the domestic, unregulated sphere. ${ }^{18}$ It is therefore not necessary to qualify the group "women" in order to remain faithful to the anti-discrimination logic of the nexus requirement. This appears to be Mr. Justice La Forest's position in A.G. $v$. Ward, where he simply listed gender without any qualification as the basis for identifying a social group because it is an innate characteristic. The Canadian Immigration and Refugee Board has endorsed this approach to defining gender-based particular social groups. In its update on the Gender Guidelines, the IRB unequivocally states that since gender is an innate characteristic, women may form a particular social group within the Con- 
vention refugee definition. ${ }^{19}$ In Fatin $v$. I.N.S. the United States Court of Appeals for the Third Circuit also endorsed a similar position when it emphasized that an Iranian applicant who feared persecution because she is a woman can be a member of a particular social group. ${ }^{20}$

Recognizing that women may constitute a particular social group does not, of course, automatically make all women eligible for Convention refugee protection. In view of the individualized focus of refugee protection, a woman will have to establish her membership in the group that is demonstrably susceptible to persecution. Thus, eligibility for refugee protection based on gender defined social group turns on whether a woman has a wellfounded fear of persecution in her home country because of membership in this group. In Cheung v. M.E.I., the Federal Court of Appeal pointed out that recognizing that women in China who have more than one child and threatened with sterilization constitute a particular social group did not automatically make all women in the group eligible for Convention refugee protection. "It is only those women who also have a well-founded fear of persecution as a result of that who can claim such status." 21

Whereas in some countries, all women may be vulnerable to serious human rights violations, in many countries only a subset of the population of women will be at risk. In such cases, gender will be one form of civil or political status that together with an intersecting ground of claim (such as race, religion or other innate or fundamental characteristics), will combine to define the particular social group. In view of the anti-discrimination purpose of refugee protection, these other characteristics should be immutable in the sense of being either innate or so fundamental to the identity or basic human dignity of the members that requiring them to forsake their belief will constitute a violation of their basic human rights. For instance, the Gender Guidelines Update recognizes that in addition to women being a particular social group, there may also be other particular social groups made up of subgroups of women. These groups may be identified by reference to other immutable characteristics such as age, race, marital status or economic status. ${ }^{22}$

For example, in the Fatin case, the appellant's primary argument was not that she was at the risk of persecution simply because she is a woman. Instead, she alleged that she risked harm as a member of a "very visible and specific subgroup: Iranian women who refuse to conform to the government's gender-specific laws and social norms." ${ }^{23}$ The U.S. Court of Appeals found that the at-risk group did not include all Iranian women who hold feminist views, or even all those who object to the gender-specific rules in Iran. The group at risk of persecution is limited to those women who hold a particularly strong political or religious opinion in opposition to the policies of the theocratic state. This category meets the test for a particular social group, since it combines two forms of immutable status, namely gender and political or religious opinion.

Similarly, in Zekiye Incirciyan, ${ }^{24}$ the Immigration Appeal Board held that "single women living in a Moslem country without the protection of a male relative" constitute a particular social group. In this case, gender was combined with other characteristics to define the social group to which the claimant belongs. In his commentary on the Incirciyan decision, Hathaway justifies the identification of the social group as conforming to the anti-discrimination approach by pointing out that members have no control over their gender or absence of male relatives. He also notes that choice of marital status is a fundamental human right that no one should be required to relinquish. In view of the position that particular social groups ought to be defined in terms of vulnerabilities in general rather than by reference to particular forms of harms, perhaps the social group of which Incirciyan is a member should have been simply "unmarried women."
Following from the immutability test, the particular social group in Cheung ought to have been identified as "women in China who have more than one child." This group is united not only be gender but also by a common conviction-reproductive liberty - which is so fundamental to their human dignity that they should not be required to alter it. Of course, not all women in China with more than one child will be eligible for refugee status. As rightly pointed out by $\mathrm{Mr}$. Justice Linden, only those women who have a well-founded fear of persecution by reason of their status can claim refugee protection. Since forced sterilization is not an innate or unchangeable characteristic, it should not be the basis for defining the social group. This approach also ensures that eligibility for refugee protection is not limited to women threatened with forced sterilization but to those facing other forms of persecution as a result of having more than one child.

In sum, there have been considerable developments regarding the particular social group category. It is now settled that a social group can be defined by the gender of its members. Although the determination of refugee status remains a national prerogative of states, there has, however, been willingness at both regional and national levels to recognize women as constituting a particular social group, meaning that women confronted with the risk of gender-related persecution solely because of their gender are eligible for refugee protection based on the social group category. Whereas all women are part of a social group, only those who are likely to be victimized or marginalized because of their gender will be eligible for Convention refugee protection as these will be the only persons within the category who are genuinely at risk of persecution. The class of at-risk women may sometimes be defined by reference to gender and other innate or fundamental characteristics, rather than the common victimization, which distinguishes women in need of refuge from the general population. 


\section{Notes}

1. J. C. Hathaway, The Law of Refugee Status (Toronto: Butterworths, 1991), 162.

2. A.G. v. Ward [1993] 2 S.C.R. 689 at 739.

3. Ibid., at 739.

4. See Immigration and Refugee Board, Women Refugee Claimants Fearing Genderrelated Persecution, 5-6 (1993).

5. Ibid., at 6.

6. 97 D.L.R. (4th) 729 (1992).

7. [1993] 3 F.C. 314 (F.C.A.).

8. Ibid., at 87.

9. [1995] 2 F.C. 55 at 60; see also Diluna v. M.E.I. (1995), 29 IMM. L.R. (2d) 156.

10. IRB Decision T92-03227, November 18 , 1992 , at 6.

11. See F. Stairs and L. Pope, "No Place Like Home: Assaulted Migrant Women's Claims to Refugee Status" (1990), 6, Journal of Law \&Society 148, at 171;A. Macklin, "Canada (Attorney General) v. Ward: A Review Essay," 6(3) INT'L J. REF. L. 362, 377 (1994); "Refugee Women and the Imperative of Categories," 17 HUM. RTSQ.214, 246-47 (1995).

12. See Stairs and Pope, op. cit., at 166-67.

13. [1989] 1 S.C.R. 1219 (S.C.C.).

14. Ibid., at 1247. See also Janzen v. Platy Enterprises Ltd. [1989] 1 S.C.R. 1252 (S.C.C.), where the Chief Justice observed that sexual harassment need not be suffered by all women in order to qualify as discrimination on the basis of gender. In other words, all members of the affected gender or particular group need not be treated identically before discrimination on the basis of a group characteristic can be recognized. In this case, the fact that other female employees were not sexually harassed did not negate the claim of the appellants that they had been victims of sex discrimination while working for the respondents. The critical fact in this case was that it was only women employees who ran the risk of sexual harassment.

15. For instance, the world community affirmed this perception in the Declaration on the Elimination of Violence against Women, 1994. The preamble to the Declaration recognizes the urgent need to apply fundamental human rights to women (paragraph 1). It also notes in paragraph 6 that "violence against women is a manifestation of historically unequal power relations between men and women which has led to domination over and discrimination against women by men ... and violence against women is one of the crucial social mechanisms by which women are forced into a subordinate position compared with men."

16. See Hathaway, supra note 1 , at 163.

17. Canadian Gender Guidelines, supra note 4 , at 6 .

18. Often times, violence committed against women in the public sphere receives more attention from police and judicial authorities compared with those which occur in the private familial sphere. Though fear of serious harm in the public realm may also constitute the basis of a well-founded fear of persecution, often times, the harms from which women receive no effective protection from the state of origin are those which take place in the private realm, hence the emphasis on privately inflicted violations of women's rights.

19. Immigration and Refugee Board, Women Refugee Claimants Fearing Gender-related Persecution: Update (November 1996), at 8.

20. Fatin v. I.N.S., 12 F.3d 1233 at 1240 (3rd Cir. 1995).

21. Supra note 7 , at 87.

22. Supra note 19 , at 9.

23. Supra note 20 , at 1241.

24. Immigration Appeal Board Decision M87-1541X, August 10, 1987.

\section{Refuge}

Canada's Perlodical on Refugees 18 published sux times a year by the Centro for Refugee Swdies, Yodk Universiry, Toronto.

$$
\text { Aramblefrom }
$$

Centre for Refüged Studies, Youk University

Surte 33, York Laneo 4700 Keele St:

North York ON MBIIP3

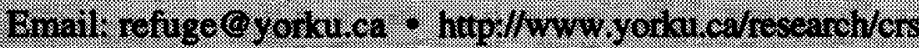

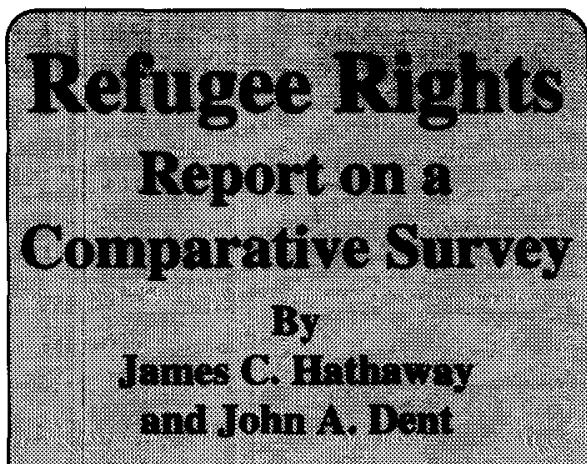

Toronto: Yorkl Lanes Fress, 1995 : DP. $82.511 .95 \cdot 1 \mathrm{SBN} 1-55014-265-6$ Are visa controls imended to keep refugees from reaching an asylum country legalh Can asylum-seekers. legitmately contest conditions of detention? At what point do refugees have the right to work or to claim social assistance?

These are anoong the many issues addressed by Refugee Rights: Report on a Compararive Survey a ground. breaking analysisof the human rights of refugees around the world. Working h collaboration with thiry renowned legal experss from Europer A rica Asia. Oceania, North America, and Latin Anierica, Professor James Mathaway. Osgoode Hall Iaw School, Tork University, and Jolan Dent, Refugee Lav. Unit, Centre for Refugee Studies, York University: analyze the international legal instruments that set the human rights of teragees. By grounding theit analysis in real-17fe challenges facing refugees today. Whathaway and Dent have produced a book as valuable to activists as to scholars.

Refuger Rishis wil provole debate on the adequacy of the internationa! refuges tights regine. it is essential reading for everyone concerined to counter threats to the human digaity of refugees.

Avilubila fromu.

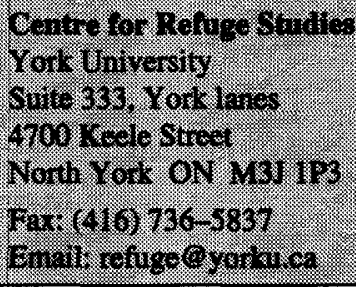

